7. Reprod. Fert. (1972) 31, 115-118

\title{
HYPOSECRETION OF GONADOTROPHINS IN ALLOXAN-TREATED MALE RATS
}

\author{
B. E. HOWLAND AND E. J. ZEBROWSKI \\ Department of Oral Biology, The University of Manitoba, \\ Winnipeg R3E OW3, Canada
}

(Received 15th February 1972, accepted 20th March 1972)

Diabetes has been reported to cause marked sexual disturbances in male rats. These include a reduction in testicular and accessory gland weights and infertility (Foglia, Borghelli, Chieri, Fernandez-Collazo, Spindler \& Wesley, 1963), reduced androgen biosynthetic activity of testicular tissue (Foglia, Rosner, Cattaneo de Peralta Ramos \& Lema, 1969) and degenerative changes in seminiferous tubules (Schöffling, Federlin, Schmitt \& Pfeiffer, 1967; Foglia et al., 1969). A reduction in gonadotrophin secretion has been suggested as a possible explanation for these disorders in diabetic rats.

Alloxan treatment is a widely used method of inducing experimental diabetes (Rerup, 1970). This report describes the short-term effects of alloxan on sex organ weights and gonadotrophin levels in male rats.

Two experiments were conducted. In Exp. 1, the rats were 59 to 69 days old (mean body weight, $309 \mathrm{~g}$ ). In Exp. 2, rats of two ages were used. Young rats were 49 to 54 days old (mean weight, $238 \mathrm{~g}$ ) while old rats were 96 to 113 days old (mean weight, $427 \mathrm{~g}$ ). The age groups were studied in separate trials carried out approximately a month apart. Plasma samples or pituitaries for both trials (Exp. 2) were assayed in the same assay run.

Sprague-Dawley rats from our own colony were used in these studies. The animals were individually caged in a temperature $\left(74 \pm 1^{\circ} \mathrm{F}\right)$ - and light $(12 \mathrm{hr}$ light/12 hr dark)-controlled room during the experiments. The animals were assigned to treatment groups, allowed several days to become accustomed to the individual cages and then fasted for $48 \mathrm{hr}$. At the end of the fasting period, the treated animals were injected intraperitoneally with alloxan monohydrate dissolved in $0.9 \%$ saline at a dose of $15 \mathrm{mg} / 100 \mathrm{~g}$ body weight. The animals were then allowed free access to Purina Lab Chow and distilled water. The urine volume was measured daily in alloxan-treated rats, and the urine glucose concentration was determined using Tes Tape (Eli Lilly \& Co.). Eight days after alloxan treatment and following an overnight (16-hr) fast, the animals were anaesthetized with ether and blood samples were obtained by heart puncture. The animals were then killed and anterior pituitaries, testes and accessory sex glands were removed and weighed. Plasma samples and anterior pituitaries were frozen until assayed for gonadotrophins.

The concentration of $\mathbf{L H}$ in pituitary homogenates and sera was determined by the $0-0$ radioimmunoassay described by Niswender, Midgley, Monroe \& Reichert (1968). The standard used was either NIH-LH-sl4 or NIAMD rat-LH- 
RP-1 and the results were expressed in terms of these preparations. A similar double antibody radioimmunoassay, distributed by the National Institute of Arthritis and Metabolic Diseases, NIH, was used to measure FSH concentration. Data for FSH were expressed in terms of NIAMD rat-FSH-RP-1.

The data were analysed by $t$ test or by analysis of variance with sums of squares adjusted for unequal subclass numbers by use of the harmonic means of N (Snedecor, 1956).

All rats treated with alloxan became diabetic, as indicated by a prompt onset of diuresis and glucosuria. Urine glucose concentrations ranged from $0 \cdot 1$ to $2 \cdot 0$ $\mathrm{g} / 100 \mathrm{ml}$ as early as $24 \mathrm{hr}$ after treatment. The mortality rate of treated rats in Exp. 1 was the same as that of controls with two of eight animals in each group dying during the course of the experiment. In Exp. 2, for young animals, seven of eleven treated rats died compared with one of nine controls; for old animals, eight of eighteen treated rats died compared with two of twelve controls. Animal losses were well within the range of reported values (Sokoloverova, 1964).

TABLE 1

MEAN BODY AND ORGAN WEIGHTS AND LH LEVELS FOR CONTROL AND ALLOXAN-TREATED RATS

\begin{tabular}{l|c|c}
\hline & \multicolumn{2}{|c}{ Treatment } \\
\cline { 2 - 3 } & Control & Alloxan \\
\hline No. of rats & 6 & 6 \\
Body wt $(\mathrm{g})^{* *}$ & $298 \pm 8^{\mathbf{a}}$ & $243 \pm 14$ \\
Testicular wt $(\mathrm{g})$ & $3 \cdot 29 \pm 0 \cdot 16$ & $3 \cdot 37 \pm 0 \cdot 16$ \\
Ventral prostate wt $(\mathrm{mg})^{*}$ & $311 \pm 14$ & $247 \pm 22$ \\
Pituitary wt $(\mathrm{mg})$ & $8 \cdot 3 \pm 0 \cdot 6$ & $7 \cdot 3 \pm 0 \cdot 2$ \\
Pituitary LH conc. $(\mu \mathrm{g} / \mathrm{mg})^{\mathbf{b}}$ & $1.97 \pm 0 \cdot 19$ & $2 \cdot 12 \pm 0 \cdot 09$ \\
Plasma LH conc. $(\mathrm{ng} / \mathrm{ml})^{\mathrm{b}}$ & $0 \cdot 88 \pm 0 \cdot 11$ & $0 \cdot 52 \pm 0 \cdot 25^{\mathrm{c}}$ \\
\hline
\end{tabular}

${ }^{a}$ Mean \pm S.E.

bH in terms of NIH-LH-s14.

$c$ Mean based on five animals.

$* P<0.05 ; * * P<0.01$.

The data collected in Exp. 1 are shown in Table 1. Alloxan treatment caused a reduction in body weight $(P<0.01)$ and ventral prostate weight $(P<0.05)$. Testicular weight and pituitary weight were not affected by treatment. Although the concentration of LH in the pituitary was similar for both groups, the mean plasma concentration of LH was not significantly lower in the alloxantreated animals than in the controls.

The results of Exp. 2 are summarized in Table 2. Old rats had heavier body and organ weights $(P<0 \cdot 01)$, lower pituitary concentrations of $\mathrm{FSH}$ and $\mathrm{LH}$ $(P<0.01)$, higher levels of plasma FSH $(P<0.01)$ and lower levels of plasma LH $(P<0.05)$ than did the young rats. Alloxan treatment caused a reduction in body weight $(P<0.01)$ and in seminal vesicle weight $(P<0.01)$. The treatment effect on seminal vesicle weight was greater in young than in old rats (treatment $\times$ age $P<0.01$ ). The concentrations of FSH and LH in the pituitary glands 
were lower $(P<0.05$ for FSH, $P<0.01$ for $\mathrm{LH})$ in alloxan-treated rats than in controls. The treatment effect on pituitary $\mathrm{LH}$ concentration appeared to be restricted to the young animals resulting in a treatment $\times$ age interaction $(P<0 \cdot 01)$. Plasma levels of $\mathrm{LH}$ and FSH were also found to be lower in alloxantreated rats than in control rats $(P<0.05)$.

The results of these experiments suggest that alloxan treatment initially causes a reduction in body weight and accessory sex gland weight as well as a reduction in both pituitary and plasma levels of gonadotrophins. In general, the effects of alloxan treatment on accessory sex glands and gonadotrophin levels tended to be greater in young than in old rats. The fact that both plasma

TABLE 2

EFFECT OF AGE AND ALLOXAN TREATMENT ON BODY AND ORGAN WEIGHTS AND GONADOTROPHIN LEVELS IN RATS

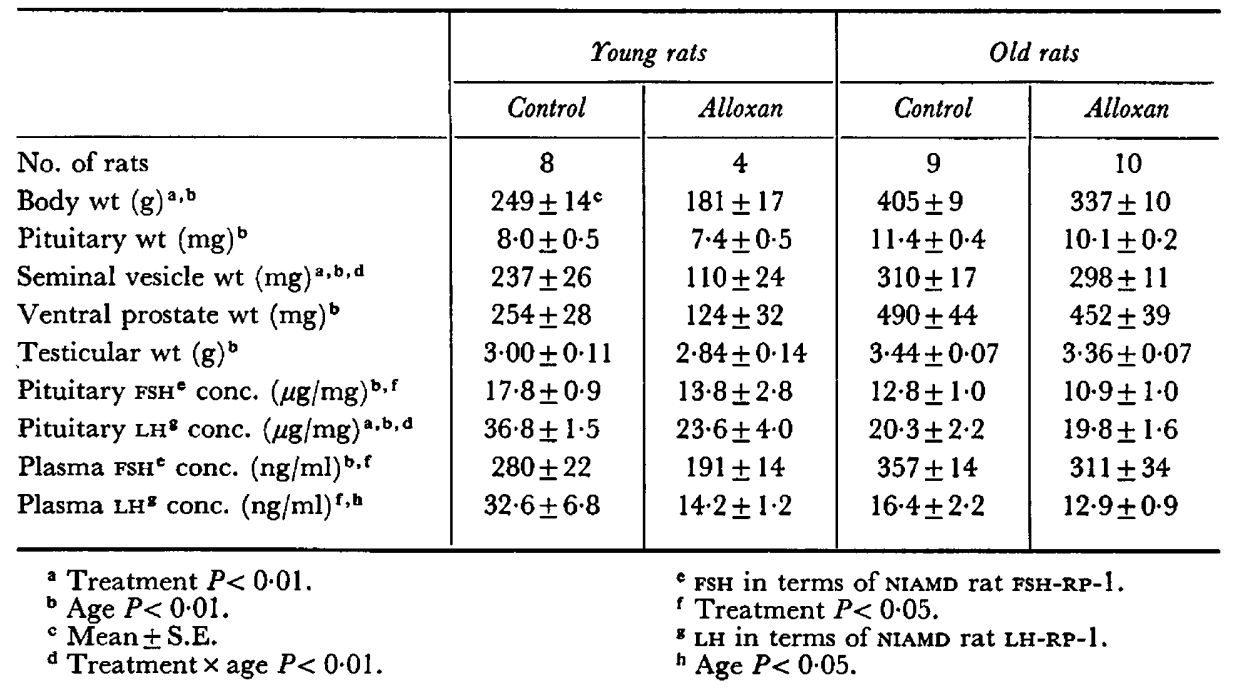

and pituitary levels of FSH were lower in treated rats compared to control rats suggests that the rate of synthesis as well as the release of hormone had been affected. The same interpretation could explain the LH levels in the young animals. In the older animals, however, the reduction in plasma LH concentration caused by treatment was not accompanied by a reduction in the pituitary concentration of hormone. The latter observation may suggest that alloxan treatment affected primarily the release mechanisms in the older rats.

The reduction in $\mathrm{LH}$ levels in treated rats may have reduced androgen secretion by the testes which subsequently resulted in reduced accessory sex gland weight. However, the possibility that treatment reduced the responsiveness of the accessory sex glands to androgen or of Leydig cells to LH cannot be ruled out. Farina, Chieri, Basabe \& Foglia (1971) have reported that ovarian tissue from diabetic female rats shows a reduced ability to respond to gonadotrophins.

It is unknown whether the treatment effects observed were due to the diabetic state, to other physiological changes induced by alloxan or were, in fact, a direct 
result of alloxan. Alloxan has been reported to produce toxic effects on kidney and liver tissue (Rerup, 1970) and to increase adrenal weight and plasma corticosteroid levels (Saba \& Hoet, 1962). During the first 6 to 8 days following alloxan administration, feed consumption is significantly reduced (N. S. Ramamurthy \& E. J. Zebrowski, unpublished observations). Thus, direct toxic effects of alloxan, diabetes, adrenal hypersecretion and undernutrition may all be factors contributing to the changes in gonadotrophin secretion and accessory sex gland weights observed 8 days after alloxan administration.

The authors are grateful to Dr G. D. Niswender, Dr L. E. Reichert, Jr, the Endocrine Study Section, NIH and the National Institute of Arthritis and Metabolic Diseases, Rat Pituitary Hormone Program, for providing the materials used in the radioimmunoassays. This study was supported by grants MA-4454 and MA-3627 from the Medical Research Council of Canada.

\section{REFERENGES}

Farina, J. M. S., Chieri, R. A., Basabe, J. C. \& Foglia, V. G. (1971) Response to gonadotrophins in mature and immature diabetic rats. Fert. Steril. 22, 794.

Foglia, V. G., Borgheldi, R. F., Chieri, R. A., Fernandez-Collazo, E. L., Spindler, I. \& Wesley, O. (1963) Sexual disturbances in the diabetic rat. Diabetes, 12, 231.

Foglia, V. G., Rosner, J. M., Cattaneo de Peralta Ramos, M. \& Lema, B. E. (1969) Sexual disturbances in the male diabetic rat. Horm. Metab. Res. 1, 72.

Niswender, G. D., Mtogley, A. R., JR, Monroe, S. E. \& Retchert, L. E., Jr (1968) Radioimmunoassay for rat luteinizing hormone with anti-ovine $\mathrm{LH}$ serum and ovine $\mathrm{LH}_{-}{ }^{131} \mathrm{I}$. Proc. Soc. exp. Biol. Med. 128, 807.

ReruP, C. C. (1970) Drugs producing diabetes through damage of the insulin secreting cells. Pharmacol. Rev. 22, 485.

SABA, G. C. \& HoET, J. J. (1962) The effect of alloxan on the adrenal cortical secretion. I. In male rats. Acta endocr., Copenh. 40, 349.

Schöffling, K., Federlin, K., Schmitt, W. \& Pfeiffer, E. F. (1967) Histometric investigations on the testicular tissue of rats with alloxan diabetes and Chinese hamsters with spontaneous diabetes. Acta endocr., Copenh. 54, 335.

SNedecor, G. W. (1956) Statistical methods, 5th edn. Iowa State College Press, Ames, Iowa.

Sokoloverova, I. M. (1964) Response of male and female rats of various ages to administration of diabetogenic doses of alloxan. Fedn Proc. Fedn Am. Socs exp. Biol. 23, T399. 